\title{
Tingkat keragaman ukuran benih ikan lele Clarias sp. yang diberi Artemia dengan periode yang berbeda
}

\section{Size variation of catfish Clarias sp. larvae given Artemia in different period}

\author{
Dedi Jusadi*, Farida Fitriani, Julie Ekasari, Apriana Vinasyiam \\ Departemen Budidaya Perairan, Fakultas Perikanan dan Ilmu Kelautan, Institut Pertanian Bogor \\ Kampus IPB Dramaga Bogor, Jawa Barat 16680 \\ *Surel: siflounder@gmail.com
}

\begin{abstract}
This research was conducted to evaluate the effect of different Artemia feeding period on the size variation of catfish Clarias sp. larvae. One thousand two days post hatched larvae with an average body length of $0.7 \pm 0.03 \mathrm{~cm}$ were randomly distributed into $25 \mathrm{~L}$ round plastic tanks. The treatment conducted for 13 days with four treatment; without Artemia, given Artemia 1, 2, or 3 days in the first culture period. The results showed that 15 days old fish has the same survival rate in all treatments; and has two size distribution i.e. the small size (S) and medium size (M). Increasingly the period of administration of Artemia, the percentage of the amount of M-size fish increases, thereby giving Artemia were able to increase growth of larvae. Feeding catfish with Artemia for two days has shown producing better growth.
\end{abstract}

Keywords: catfish, Artemia, size variation, growth performance

\begin{abstract}
ABSTRAK
Penelitian ini dilakukan untuk mengevaluasi pengaruh perbedaan periode pemberian pakan Artemia terhadap kinerja pertumbuhan larva ikan lele Clarias sp. Seribu ekor larva lele yang berumur dua hari dengan panjang rata-

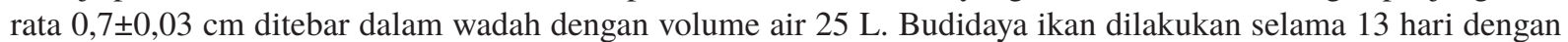
empat perlakuan, yaitu perlakuan tanpa pemberian Artemia, pemberian Artemia selama satu, dua, atau tiga hari di awal masa budidaya. Hasil penelitian menunjukkan bahwa ikan umur 15 hari memiliki sintasan yang sama di semua perlakuan, serta memiliki dua sebaran ukuran, yakni ukuran kecil (S) dan ukuran sedang (M). Semakin lama periode pemberian Artemia, persentase jumlah ikan ukuran M meningkat, sehingga pemberian Artemia pada larva ikan lele mampu meningkatkan pertumbuhan. Pemberian Artemia selama dua hari memberikan pertumbuhan yang lebih baik.
\end{abstract}

Kata kunci: ikan lele, Artemia, keragaman ukuran, kinerja pertumbuhan

\section{PENDAHULUAN}

Segmen pertama dalam usaha pembenihan adalah budidaya larva dari sejak telur menetas sampai menghasilkan benih umur sekitar dua minggu. Pada segmen ini, petani memberikan pakan cacing sutra dari awal larva makan hingga larvaberumur7-8hari. Selanjutnyalarvalelediberi kombinasi pakan buatan dan cacing sutra hingga berumur 12-13 hari atau hingga panen. Pada saat pemanenan, akan dilakukan pengelompokkan benih berdasarkan ukuran (grading) yang menghasilkan benih dengan ukuran S (kecil), $\mathrm{M}$ (sedang), L (besar), dan J (jumper). Ikan yang dipanen pada kegiatan pembenihan rata-rata menghasilkan benih berukuran S sebanyak $60 \%$, ukuran M sebanyak 28\%, dan ukuran J sebanyak
5\% (komunikasi personal dengan pembudidaya lele di Daerah Cibanteng, Kecamatan Ciampea, Kabupaten Bogor). Hasil penelitian pendahuluan menunjukkan bahwa pemberian cacing sutra sebagai pakan awal larva menghasilkan ikan ukuran L sebanyak $27,17 \%$, dan ikan ukuran S sebanyak $72,83 \%$. Tingginya persentase ukuran $S$ yang dihasilkan, diduga berkaitan dengan penggunaan cacing sutra sebagai pakan awal larva. Cacing sutra memiliki ukuran panjang 9-35 mm dengan diameter badan 0,8-0,9 mm, sedangkan larva ikan lele menurut Morioka et al. (2013) dengan ukuran 6,3 mm memiliki bukaan mulut kecil, yaitu $\pm 0,455 \mathrm{~mm}$. Dengan demikian, pemangsaan cacing sutra sebagai pakan awal larva diduga akan membutuhkan energi yang besar, sehingga mayoritas larva tumbuh lebih 
lambat. Ukuran pakan akan mempermudah dan meningkatkan efisiensi ikan mendapatkan pakan. Larva perlu diberikan pakan awal yang ukurannya lebih kecil dari cacing sutra. Penggantian pakan awal tersebut diharapkan dapat mengurangi presentase ukuran S larva, dan larva akan tumbuh lebih seragam. Salah satu pakan yang dapat mengganti cacing sutra dan diberikan sebagai pakan awal larva adalah Artemia. Naupli Artemia memiliki ukuran 400-500 $\mu$ m (Stottrup et al., 2003). Artemia mudah didapatkan, mudah diserap dan memiliki nutrisi yang cukup untuk larva (Conceicao et al., 2010). Menurut Hang et al. (1999) pemberian pakan menggunakan Artemia mampu meningkatkan bobot larva ikan Pangasius bocaurti.

Pemberian pakan Artemia sebagai pakan awal larva telah umum dilakukan pada ikan patin. Morioka et al. (2010) serta Singh dan Lakra (2012) menunjukkan bahwa pemberian Artemia selama tiga hari meningkatkan kinerja pertumbuhan larva ikan P. bocaurti. Namun demikian, penggunaan Artemia belum banyak dilakukan pada ikan lele. Oleh karena itu penelitian ini dilakukan untuk menentukan periode pemberian Artemia yang paling optimum dalam meningkatkan ukuran dan keseragaman ikan lele.

\section{BAHAN DAN METODE}

\section{Budidaya ikan}

Larva ikan lele diperoleh dari hasil pemijahan yang dilakukan sendiri di daerah Cibanteng, Bogor. Larva berumur dua hari dengan panjang $0,70 \pm 0,03 \mathrm{~cm}$ ditebar ke dalam delapan wadah berdiameter $40 \mathrm{~cm}$ yang diisi air sebanyak $25 \mathrm{~L}$. Larva ditebar dengan kepadatan 40 ekor/L dan dipelihara selama 13 hari hingga berumur 15 hari. Selama masa budidaya, larva diberi pakan sesuai perlakuan.

Wadah budidaya diberi satu buah aerasi untuk menjaga konsentrasi oksigen dalam air tetap tinggi. Penyiponan dan pergantian air dilakukan setiap pagi sebanyak $10 \%$. Suhu dan kandungan oksigen terlarut diukur setiap pagi dan sore hari, sedangkan $\mathrm{pH}$ dan konsentrasi amonia diukur pada hari pertama dan kedelapan masa budidaya ikan. Kualitas air media pemeliharaan selama masa budidaya disajikan pada Tabel 1 .

\section{Pemberian pakan}

Pakan yang diberikan untuk larva ikan lele berupa naupli Artemia, cacing sutra, dan pakan buatan. Larva yang berumur dua hari mulai diberikan perlakuan dengan periode pemberian pakan yang berbeda sesuai dengan perlakuan (Tabel 2). Pemberian pakan cacing sutra dilakukan pada pukul 06.00, 11.00, 16.00, dan 21.00 WIB. Naupli Artemia diberikan setiap empat jam (06.00, 10.00, 14.00, 18.00, 22.00, dan $02.00 \mathrm{WIB})$. Setelah larva berumur sembilan hari, cacing sutra diberikan pada pukul 07.00 dan 15.00, sedangkan pakan buatan diberikan satu kali pada jam 21.00 WIB. Pakan buatan yang diberikan adalah pakan komersil Fengli 0 (powder) dan pakan Fengli 1 (0,64 mm). Pada umur 14 hari, ikan dipuasakan, selanjutnya pada umur 15 hari, ikan dipanen.

Jumlah pakan yang diberikan pada larva ikan lele dalam masing-masing wadah selama 13 hari masa budidaya disajikan pada Tabel 3. Jumah naupli Artemia yang diberikan adalah 2,43 g/ hari. Cacing sutra diberikan secara ad libitum, dengan jumlah yang ditingkatkan sesuai dengan bertambahnya umur ikan. Pemberian pakan buatan didasari pada penggantian pakan alami ke pakan buatan telah dapat dilakukan (ChepkiruiBoit et al., 2011).

\section{Panen}

Panen dilakukan pada hari ke-14 budidaya ikan (umur 15 hari). Benih dalam wadah dihitung jumlahnya, kemudian dipisahkan antara ukuran $\mathrm{S}, \mathrm{M}$, dan L dengan menggunakan alat grading.

Tabel 1. Kualitas air media budidaya pada masing-masing perlakuan selama masa pemeliharaan larva ikan lele

\begin{tabular}{lcccc}
\hline \multirow{2}{*}{ Parameter } & \multicolumn{4}{c}{ Perlakuan (jumlah hari pemberian Artemia) } \\
\cline { 2 - 5 } & 0 & 1 & 2 & 3 \\
\hline Suhu $\left({ }^{\circ} \mathrm{C}\right)$ & $25,0-32,0$ & $25,0-32,0$ & $26,0-31,5$ & $25,0-32,0$ \\
DO $(\mathrm{mg} / \mathrm{L})$ & $3,00-7,00$ & $3,10-7,10$ & $3,10-7,00$ & $3,00-7,30$ \\
$\mathrm{pH}$ & $7,90-8,17$ & $7,81-8,17$ & $7,74-8,17$ & $7,73-8,17$ \\
Amonia $(\mathrm{mg} / \mathrm{L})$ & $0,05-0,18$ & $0,05-0,16$ & $0,05-0,15$ & $0,05-0,12$ \\
\hline
\end{tabular}

Keterangan: DO = oksigen terlarut di air. 
Tabel 2. Skema jenis dan periode pemberian pakan masing-masing perlakuan selama masa budidaya larva ikan lele

\begin{tabular}{|c|c|c|c|c|c|c|c|c|c|c|c|c|c|c|}
\hline \multirow{2}{*}{ Parameter } & \multicolumn{14}{|c|}{ Perlakuan (jumlah hari pemberian Artemia) } \\
\hline & 2 & 3 & 4 & 5 & 6 & 7 & 8 & 9 & 10 & 11 & 12 & 13 & 14 & 15 \\
\hline Suhu $\left({ }^{\circ} \mathrm{C}\right)$ & \multirow{3}{*}{ A } & & & & \multirow{3}{*}{\multicolumn{2}{|c|}{$\mathrm{C}$}} & & & \multirow{3}{*}{\multicolumn{2}{|c|}{$\mathrm{C}+\mathrm{F} 0$}} & \multirow{3}{*}{\multicolumn{2}{|c|}{$\mathrm{C}+\mathrm{F} 0+\mathrm{F} 1$}} & \multirow{3}{*}{ B } & \multirow{3}{*}{$\mathrm{P}$} \\
\hline $\begin{array}{l}\mathrm{DO}(\mathrm{mg} / \mathrm{L}) \\
\mathrm{pH}\end{array}$ & & & & & & & & & & & & & & \\
\hline Amonia (g/L) & & & & & & & & & & & & & & \\
\hline
\end{tabular}

Keterangan: A=Artemia, $\mathrm{C}=$ cacing sutra, F0=Fengli 0, F1=Fengli 1, B=berok, $\mathrm{P}=$ panen.

Seluruh ikan pada setiap ulangan ditimbang dengan menggunakan timbangan digital ketelitian $0,01 \mathrm{~g}$. Bobot individu ikan didapatkan dengan membagi bobot seluruh ikan dengan jumlah ikan yang ditimbang. Panjang akhir ikan diukur menggunakan jangka sorong dengan tingkat ketelitian 0,01 cm. Pengukuran panjang dilakukan sebanyak 15 ekor untuk masing-masing ukuran ikan.

\section{Parameter uji}

Parameter yang diukur pada penelitian ini adalah tingkat kelangsungan hidup, rerata berat dan panjang akhir, koefisien keragaman panjang, serta rasio efisiensi protein (PER). Kelangsungan hidup larva dihitung pada akhir masa budidaya. Kelangsungan hidup ditentukan berdasarkan jumlah ikan yang hidup di akhir masa budidaya.

Keragama panjang dinyatakan dalam koefisien keragaman ukuran panjang yang dihitung menggunakan rumus sebagai berikut:

$$
\mathrm{CV}=\mathrm{SD} / \mathrm{L} \times 100
$$

Keterangan:

$$
\begin{aligned}
& \mathrm{CV}=\text { koefisien keragaman ukuran panjang } \\
& \mathrm{SD}=\text { standar deviasi } \\
& \mathrm{L}=\text { panjang rata-rata }
\end{aligned}
$$

PER dihitung menggunakan rumus:

$$
\mathrm{PER}=\Delta \mathrm{W} / \mathrm{Pi}
$$

Keterangan:

$\mathrm{PER}=$ rasio efisiensi protein

$\Delta \mathrm{W}=$ peningkatan biomassa ikan $(\mathrm{g})$

$\mathrm{Pi}=$ bobot protein yang dikonsumsi $(\mathrm{g})$

\section{Analisis proksimat}

Analisis proksimat dilakukan pada naupli Artemia, cacing sutra, dan pakan komersil. Analisis tersebut meliputi analisis kadar air, dan
Tabel 3. Analisis proksimat protein (\% bobot basah) pakan selama masa budidaya

\begin{tabular}{lcccc}
\hline & \multicolumn{4}{c}{ Jenis pakan } \\
\cline { 2 - 5 } Komposisi & $\begin{array}{c}\text { Naupli } \\
\text { Artemia }\end{array}$ & Cacing & F0 & F1 \\
\hline Protein & 8,29 & 9,47 & 36,14 & 33,06 \\
Air & 83,86 & 79,86 & 11,19 & 8,02 \\
\hline
\end{tabular}

Keterangan: F0=Fengli 0, F1=Fengli 1.

kadar protein dalam pakan dan dilakukan dengan mengikuti metode AOAC (2012).

\section{Analisis data}

Rancangan penelitian ini menggunakan rancangan acak lengkap (RAL) dengan empat perlakuan dan dua ulangan. Pengolahan data dilakukan menggunakan Microsoft Excel 2010, sedangkan analisis sidik ragam dilakukan dengan menggunakan program Statistical Analysis System (SAS), dilanjutkan dengan uji beda nyata menggunakan uji Duncan.

\section{HASIL DAN PEMBAHASAN}

\section{Hasil}

Jumlah pakan yang diberikan selama masa budidaya ikan lele disajikan pada Tabel 4. Hasil penelitian menunjukkan bahwa jumlah konsumsi pakan ikan lele yang diberi pakan Artemia lebih tinggi dibandingkan dengan ikan lele yang diberikan pakan cacing sutra. Larva lele di perlakuan pemberian Artemia selama dua hari di awal budidaya mengkonsumsi pakan paling banyak.

Jumlah konsumsi protein pakan yang diberikan selama masa budidaya ikan lele disajikan pada Tabel 5. Hasil penelitian menujukkan bahwa jumlah konsumsi protein pakan ikan lele yang diberi pakan Artemia lebih tinggi dibandingkan dengan ikan lele yang diberikan pakan cacing sutra. Sama halnya dengan konsumsi pakan, larva 
lele di perlakuan pemberian Artemia selama dua hari pada awal budidaya mengkonsumsi protein paling banyak.

Kinerja pertumbuhan ikan lele yang dipelihara selama 13 hari disajikan pada Tabel 6. Larva ikan lele yang diberi pakan Artemia dengan periode pemberian pakan yang berbeda memiliki kelangsungan hidup yang tidak berbeda nyata $(\mathrm{P}>0,05)$. Pemberian Artemia memberikan pengaruh yang nyata terhadap pertumbuhan larva ikan lele dibandingkan dengan pemberian pakan hanya cacing sutra. Pemberian pakan Artemia dengan periode yang berbeda menghasilkan ukuran ikan $\mathrm{M}$ lebih banyak dibandingkan dengan ikan yang hanya diberi pakan cacing sutra. Hasil penelitian ini juga menunjukkan bahwa semakin lama periode pemberian Artemia, presentase jumlah ikan ukuran $M$ semakin meningkat.

Tabel 4. Jumlah pemberian pakan (g) larva ikan lele yang diberi pakan naupli Artemia dengan periode yang berbeda selama 13 hari masa budidaya

\begin{tabular}{|c|c|c|c|c|c|}
\hline \multirow{2}{*}{ Perlakuan } & \multicolumn{4}{|c|}{ Jenis pakan } & \multirow{2}{*}{ Total pakan } \\
\hline & Artemia & Cacing & F0 & $\mathrm{F} 1$ & \\
\hline 0 & 0,00 & 254,25 & 3,60 & 1,20 & 258,57 \\
\hline 1 & 2,43 & 253,91 & 3,90 & 1,30 & 261,54 \\
\hline 2 & 4,86 & 269,93 & 3,69 & 1,23 & 279,71 \\
\hline 3 & 7,29 & 256,20 & 4,80 & 1,60 & 269,89 \\
\hline
\end{tabular}

Keterangan: 0=tanpa Artemia, 1=Artemia satu hari, 2=Artemia dua hari, 3=Artemia tiga hari, F0=Fengli 0 , $\mathrm{F} 1=$ Fengli 1 .

Tabel 5 Jumlah konsumsi protein (g) ikan lele yang diberi pakan naupli Artemia dengan periode yang berbeda selama 13 hari masa budidaya

\begin{tabular}{cccccc}
\hline \multirow{2}{*}{ Perlakuan } & \multicolumn{4}{c}{ Jenis pakan } & \multirow{2}{*}{ Total pakan } \\
\cline { 2 - 4 } & Artemia & Cacing & F0 & F1 & \\
\hline 0 & 0,00 & 24,08 & 1,30 & 0,40 & 25,77 \\
1 & 0,20 & 24,04 & 1,41 & 0,43 & 25,98 \\
2 & 0,40 & 25,56 & 1,33 & 0,41 & 27,50 \\
3 & 0,60 & 24,26 & 1,73 & 0,53 & 26,82 \\
\hline
\end{tabular}

Keterangan: $0=$ tanpa Artemia, 1=Artemia satu hari, $2=$ Artemia dua hari, $3=$ Artemia tiga hari, F0=Fengli 0 , F1=Fengli 1 .

Tabel 6. Kinerja pertumbuhan larva ikan lele yang diberi pakan naupli Artemia dengan periode yang berbeda setelah 13 hari masa budidaya

\begin{tabular}{lcrcrr}
\hline \multirow{2}{*}{ Parameter uji } & & \multicolumn{4}{c}{ Perlakuan } \\
\cline { 3 - 6 } & & 0 & 1 & 2 & \multicolumn{1}{c}{3} \\
\hline Kelangsungan hidup (\%) & & $89,50 \pm 1,63 \mathrm{a}$ & $91,80 \pm 3,46 \mathrm{a}$ & $88,00 \pm 9,69 \mathrm{a}$ & $83,70 \pm 18,46 \mathrm{a}$ \\
Jumlah ikan (\%) & $\mathrm{S}$ & $37,40 \pm 2,73 \mathrm{a}$ & $30,40 \pm 9,86 \mathrm{ab}$ & $14,60 \pm 6,03 \mathrm{bc}$ & $8,60 \pm 3,10 \mathrm{c}$ \\
& $\mathrm{M}$ & $62,60 \pm 2,81 \mathrm{c}$ & $69,60 \pm 9,86 \mathrm{bc}$ & $85,40 \pm 6,03 \mathrm{ab}$ & $91,40 \pm 3,10 \mathrm{a}$ \\
Koefisien keragaman & $\mathrm{S}$ & $9,70 \pm 0,94 \mathrm{a}$ & $8,70 \pm 0,45 \mathrm{a}$ & $5,20 \pm 1,37 \mathrm{~b}$ & $6,00 \pm 0,77 \mathrm{~b}$ \\
panjang (\%) & $\mathrm{M}$ & $7,70 \pm 0,89 \mathrm{a}$ & $7,30 \pm 4,56 \mathrm{a}$ & $10,30 \pm 5,26 \mathrm{a}$ & $10,60 \pm 3,69 \mathrm{a}$ \\
Panjang ikan (cm) & $\mathrm{S}$ & $2,20 \pm 0,00 \mathrm{a}$ & $2,20 \pm 0,08 \mathrm{a}$ & $2,30 \pm 0,02 \mathrm{a}$ & $2,20 \pm 0,09 \mathrm{a}$ \\
& $\mathrm{M}$ & $2,90 \pm 0,01 \mathrm{a}$ & $2,70 \pm 0,01 \mathrm{a}$ & $2,80 \pm 0,04 \mathrm{a}$ & $2,80 \pm 0,18 \mathrm{a}$ \\
Bobot individu ikan (g) & $\mathrm{S}$ & $0,10 \pm 0,01 \mathrm{a}$ & $0,07 \pm 0,03 \mathrm{a}$ & $0,10 \pm 0,01 \mathrm{a}$ & $0,07 \pm 0,01 \mathrm{a}$ \\
& $\mathrm{M}$ & $0,18 \pm 0,02 \mathrm{a}$ & $0,14 \pm 0,03 \mathrm{a}$ & $0,20 \pm 0,03 \mathrm{a}$ & $0,16 \pm 0,07 \mathrm{a}$ \\
Rasio efisiensi protein & & $4,30 \pm 0,39 \mathrm{a}$ & $4,20 \pm 0,87 \mathrm{a}$ & $5,20 \pm 0,76 \mathrm{a}$ & $4,30 \pm 0,82 \mathrm{a}$ \\
\hline
\end{tabular}

Keterangan: 0=tanpa Artemia, 1=Artemia satu hari, $2=$ Artemia dua hari, $3=$ Artemia tiga hari. Nilai $=$ rerata \pm simpangan baku. Huruf pada baris yang sama menunjukkan perbedaan nyata $(\mathrm{P}<0,05)$. 
Pemberian pakan Artemia dengan periode berbeda juga meningkatkan keseragaman ikan ukuran S. Hasil penelitian menunjukkan koefisien keragaman panjang ikan ukuran $\mathrm{S}$ yang berbeda pada pemberian Artemia dengan periode berbeda. Panjang dan bobot individu ikan yang diukur pada akhir budidaya menunjukkan hasil yang tidak berbeda nyata. Nilai PER menunjukkan pemberian pakan Artemia tidak berbeda nyata dengan pemberian pakan hanya cacing saja.

Analisis usaha produksi benih ikan lele disajikan pada Tabel 7. Ikan lele dijual dengan harga Rp20 untuk ukuran S, dan Rp60 untuk ukuran M. Harga pakan Fengli 0, Fengli 1, dan cacing sutra adalah Rp20/g, dan harga Artemia adalah Rp1.000/g. Hasil analisis usaha menunjukkan bahwa keuntungan yang didapatkan dengan perlakuan pemberian pakan Artemia lebih tinggi dibandingkan dengan perlakuan pemberian pakan cacing sutra. Ikan lele dengan perlakuan Artemia selama dua hari menghasilan keuntungan yang paling banyak.

\section{Pembahasan}

Pemberian Artemia pada stadia awal larva tidak berpengaruh nyata terhadap kelangsungan hidup ikan lele pada penelitian ini. Namun, pemberian Artemia, terutama selama dua dan tiga hari pertama, dapat meningkatkan pertumbuhan larva yang dicirikan dengan semakin banyaknya persentase ikan berukuran M. Peningkatan jumlah ukuran M setelah pemberian Artemia, diduga karena ukuran pakan Artemia yang berkisar antara 400-500 $\mu \mathrm{m}$ (Stottrup et al., 2003) yang sesuai dengan bukaan mulut larva. Ukuran pakan tersebut memberikan peluang lebih banyak larva untuk mendapatkan pakan sedini mungkin dengan jumlah yang cukup. Menurut Melianawati et al. (2012), kesesuaian jenis, ukuran, dan ketersediaan pakan alami sangat menentukan tingkat konsumsi pakan larva tersebut. Pakan yang sesuai akan memberikan energi yang cukup untuk pertumbuhan larva.
Meskipun ikan dapat memangsa cacing sutra dan memanfaatkan cacing sebagai pakan dengan menggunakan giginya, ukuran pakan yang terlalu besar akan meningkatkan kebutuhan energi untuk aktivitas makan. Bila energi banyak digunakan untuk memangsa pakan, maka pertumbuhan ikan akan lebih rendah. Oleh karena itu, pemberian pakan dengan cacing sutra dan Artemia satu hari menghasilkan ikan yang tumbuh lebih rendah dibandingkan dengan pemberian Artemia dua dan tiga hari. Rendahnya pertumbuhan larva pada perlakuan cacing sutra dan Artemia satu hari menunjukkan bahwa banyak larva yang tidak mampu mengkonsumsi pakan yang diberikan. Hal ini diduga karena larva dengan ukuran $7,0 \pm 0,3 \mathrm{~mm}$ pada umur dua hari, memiliki ukuran bukaan mulut 0,495 $\mathrm{mm}$ (Morioka et al., 2013), sedangkan pakan awal yang diberikan berupa cacing sutra memiliki ukuran 9-35 mm (Shafruddin et al., 2005). Akibatnya, kesempatan larva dalam mendapatkan pakan berbeda, sehingga ukuran larva akan berbeda. Hal ini terlihat dengan tingginya nilai keragaman ikan ukuran S pada perlakuan cacing sutra dan Artemia satu hari dibandingkan dengan nilai keragaman pada perlakuan Artemia dua dan tiga hari.

Pemberian Artemia yang ukurannya sesuai untuk larva di awal masa budidaya memberikan kesempatan lebih besar pada larva mendapatkan pakan, sehingga pemberian Artemia yang semakin lama akan menjadikan penyerapan pakan oleh ikan semakin banyak. Menurut SilvaCarrillo et al. (2012), Cabral et al. (2013), dan Hu et al. (2013), pertumbuhan terjadi apabila larva mampu mengkonsumsi pakan yang diberikan. Nutrisi yang terkandung dalam pakan akan diserap oleh tubuh larva. Oleh karena itu, pada awal budidaya, ikan yang diberi Artemia akan tumbuh lebih cepat dibandingkan dengan ikan yang diberi cacing sutra. Akibatnya setelah ikan diberi cacing sutra, maka jumlah cacing sutra yang diberikan lebih banyak karena pemberian pakan tersebut disesuaikan dengan kebutuhan

Tabel 7. Perbandingan analisis usaha produksi benih ikan lele (1.000 ekor) yang diberi pakan naupli Artemia dengan periode yang berbeda

\begin{tabular}{cccc}
\hline Perlakuan & Pendapatan $(\mathrm{Rp})$ & Biaya pakan $(\mathrm{Rp})$ & Keuntungan kotor $(\mathrm{Rp})$ \\
\hline 0 & 40.280 & 5.180 & 35.100 \\
1 & 43.950 & 6.272 & 37.678 \\
2 & 47.750 & 7.807 & 39.943 \\
3 & 47.210 & 8.850 & 38.360 \\
\hline
\end{tabular}

Keterangan: $0=$ tanpa Artemia , 1=Artemia satu hari, $2=$ Artemia dua hari, $3=$ Artemia tiga hari. 
ikan, sehingga nilai PER pada setiap perlakuan tidak berbeda nyata.

Hasil analisis usaha pada Tabel 7 menunjukkan bahwa pemberian Artemia pada dua hari budidaya awal larva lele memberikan keuntungan paling tinggi dibanding perlakuan lain. Hasil analisis usaha ini dapat menjadi acuan untuk menentukan lama pemberian Artemia yang optimal, karena beberapa parameter biologis menghasilkan nilai yang tidak berbeda nyata. Dengan demikian, Artemia optimal diberikan selama dua hari pertama masa budidaya larva lele.

\section{KESIMPULAN}

Pemberian Artemia pada awal pemeliharaan larva memberikan pertumbuhan ikan lele Clarias sp. yang lebih baik dibandingkan dengan hanya pemberian cacing sutra. Pemberian Artemia selama dua hari merupakan perlakuan yang memberikan hasil terbaik berdasarkan jumlah ikan ukuran $\mathrm{M}$ dan analisis usaha.

\section{DAFTAR PUSTAKA}

[AOAC] Association of Oficial Analytical Chemists. 2012. Official Methods of Analysis, $19^{\text {th }}$ ed. Airlington: AOAC.

Cabral EM, Fernandes TJR, Campos SD, CastroCunha M, Oliveira MBPP, Cunha LM, Valente LMP. 2013. Replacement of fish meal by plant protein sources up to $75 \%$ induces good growth performance without affecting flesh quality in on growing Senegalese sole. Aquaculture 380: 130-138.

Chepkirui-Boit V, Ngugi CC, Bowman J, OyooOkoth E, Rasowo J, Mugobundi J, Cherop L. 2011. Growth performance, survival, feed utilization and nutrient utilization of African catfish Clarias gariepinus larvae co-fed Artemia and a micro-diet containing freshwater atyid shrimp Caridina nilotica during weaning. Aquaculture Nutrition 17: 82-89.

Hu L, Yun B, Xue M, Wang J, Wu X, Zheng Y, Han F. 2013. Effects of fish meal quality and fish meal substitution by animal protein blend on growth performance, flesh quality and liver histology of Japanese seabass Lateolabrax japonicus. Aquaculture 372: 52-61.

Melianawati R, Astuti NWW, Slamet B. 2012. Pola pertumbuhan larva ikan kerapu raja sunu Plectropoma laevis LACEPEDE, 1801 dan tingkat konsumsinya terhadap zooplankton rotifer Brachionus plicatilis. Jurnal Ilmu dan Teknologi Kelautan Tropis 4: 217-228.

Morioka S, Sano K, Phommachan P, Vongvichith B. 2010. Growth and morphological development of laboratory-reared larval and juvenile Pangasianodon hypophthalmus. Ichthyological Research 57: 139-147.

Morioka S, Vongvichith B, Phommachan P, Chantasone P. 2013. Growth and morphological development of laboratoryreared larval and juvenile bighead catfish Clarias macrocephalus Siluriformes: Clariidae. Ichthyology Research 60: 16-25.

Silva-Carrillo Y, Hernández C, Hardy RW, González-Rodríguez B, CastilloVargasmachuca S. 2012. The effect of substituting fish meal with soybean meal on growth, feed efficiency, body composition and blood chemistry in juvenile spotted rose snapper Lutjanus guttatus (Steindachner, 1869). Aquaculture 364: 180-185.

Singh AK, Lakra WS. 2012. Culture of Pangasianodon hypophthalmus into India: impacts and present scenario. Pakistan Journal of Biological Sciences 15: 19-26.

Stottrup J G, McEvoy L A. 2003. Live Feeds in Marine Aquaculture. Blackwell Science, USA. 